Meta

Journal des tradlucteurs

Translators' Journal

\title{
Suprasentential Semantics and Translation
}

\section{Hildegund Bühler}

Volume 24, numéro 4, décembre 1979

URI : https://id.erudit.org/iderudit/002177ar

DOI : https://doi.org/10.7202/002177ar

Aller au sommaire du numéro

Éditeur(s)

Les Presses de l'Université de Montréal

ISSN

0026-0452 (imprimé)

1492-1421 (numérique)

Découvrir la revue

Citer cet article

Bühler, H. (1979). Suprasentential Semantics and Translation. Meta, 24(4),

451-458. https://doi.org/10.7202/002177ar d'utilisation que vous pouvez consulter en ligne.

https://apropos.erudit.org/fr/usagers/politique-dutilisation/ 


\section{Suprasentential Semantics and Translation*}

HILDEGUND BÜHLER

\section{Introductory Remark}

By way of introduction let me say a few words explaining my approach to translation theory, which is not only that of a linguist but also that of a translator in close contact with the practical problems of the profession. My concern is therefore neither translation as a purely linguistic phenomenon nor the teaching of translation to future translators or its use in the foreign language classroom, but rather the attempt to bridge the gap between theory and practice of translation by investigating what professional translators can expect from, or perhaps also contribute to, the science of translation as it has developed during this past decade. But while such mutual benefit might still remain tentative, the hopes for a fruitful interrelation between linguistics and translation research that were expressed some years ago have been realized in the meantime. To make a number of suggestions in this direction will, therefore, be the second and in a way complementary purpose of this paper.

\section{Nature of Translation}

Before dealing with my subject of SUPRASENTENTIAL SEMANTICS AND TRANSLATION, however, I would like to make a few statements concerning the nature of translation that seem important in the context of this paper.

2.1. Translation, as we know, is to be regarded both as a process and a product. As to the process, which has been termed the "most complex type of event yet produced in the evolution of the cosmos 》 (as quoted in Wilss 1977:133), I would like to draw your attention once more to the following fact : if we regard translation as a communication process, i.e. the transfer of a message from source language to target language with the translator as mediating agent in a double function of receptor and source, we should not forget the fact that in human translation there is no direct transfer from source language to target language systems, but that there must be an intermediate link, whether we call it das Gemeinte (cf. Koller 1974) or sense (cf. Seleskovitch 1977), the non-verbal nature of which is a reality to the translator's introspection. Thus, as Seleskovitch

Paper read at the 5th International Congress of Applied Linguistics, August 1978, Montreal. 
has recently pointed out, (written) translation does not differ essentially from (oral) interpretation in the nature of the translation process. But while the translator initially also proceeds from linguistic meaning to sense and from sense to expression of sense, he goes one step further than the interpreter by trying to adjust the expression of sense to the linguistic meaning of the original language (in quoting Seleskovitch 1977:83 I am using her terminology), or, in other words, the translator tries in the restructuring phase to approach the surface structure of the source text. The method of Sigmund Freud, who was also a translator of parts, reported by Seleskovitch as having closed his book with the original text before translating a passage and thus achieving brilliant and rapid translations, might indeed not be very common (cf. Seleskovitch 1977:83). Yet for me, too, the most rapid and reliable method of translation (both speed and reliability being important for professional work) seems to be to translate more or less from memory, i.e. by only retaining the sense, and to approach the source text in its surface structure, as far as seems possible and desirable, only in subsequent revisions of the translation product. (May I suggest a systematic study of successive drafts of translations for a descriptive study of the translation process.) It might also be mentioned here that the method of requiring students to take notes as in consecutive interpretation as a preliminary exercise for written translation was suggested as a valuable teaching tool in the training of translators at the University of Vienna's Interpreters' Institute (cf. Kaiser 1975).

2.2. Translation as a product is a textual phenomenon. A translator's input and output are texts that for our purpose could be defined as cohesive stretches of language that are to be and have been translated (cf. also Dressler 1973:12). Therefore research in the field of textlinguistics (Textlinguistik) or the more general field of discourse studies (Textwissenschaft) (for terminological distinctions cf. van Dijk 1978) as is presently carried out in Europe deserves our close attention as to possible implications for the theory and practice of translation (cf. also Dressler 1974). Such interrelations between the two fields have been made the object of this study, the essence of which has already been indicated in its title, suprasentential phenomena being of relevance for translation mainly in the realm of semantics. The fact that textsyntax (Textsyntax) cannot be relevant for interpreters has already been stated by Dressler (1970). It can only be of secondary importance for translators in what we might term the revision stage in the light of what has been said above as to the nature of the translation process. In fact, a recent paper by Enkvist (1977) on contrastive textlinguistics and translation dealing with the subject of functional sentence perspective and related approaches has not been too convincing either, for its points are only of marginal interest for the practice of translation.

2.3. What remains are two areas where in my opinion (which is that of a professional translator) textlinguistics or discourse studies can contribute to, or benefit from, translation studies, the first of which, text typology, has already been exploited to some extent, while the second one, source text analysis, appears to be the most promising area of future cooperation. 


\section{Text Typology}

The principle of differentiating between sorts or types of texts (Textsorten, Texttypen) has received increasing attention by linguists during the past years and, as it has at a comparatively early stage been linked with translation theory, it seems to be regarded as the foremost field of contact between textlinguistics and translation (cf. the chapter on Textlinguistik und Übersetzung in Wilss 1977). It can be applied to both source texts and translation texts.

3.1. A suggestion earlier made by Dressler (1972) that translations might represent separate sorts of texts (eigene Textsorten) emitting signals thereof was recently taken up in an interdisciplinary study in cooperation with computational linguistics at the University of Vienna (Kratky 1976), confirming the fact, wellknown to translators when calculating their fees, that there is often a considerable discrepancy between the lengths of source and translation texts. The outcome of this study - all of the translation texts investigated were found to contain more letters than would be justified by the averages calculated for the respective target languages - was attributed by the author to what he called Verkomplizierung (overcomplication) of the translation texts due to the fact that translators tend to imitate the surface structures of the source texts and taken as proof of Dressler's proposition. I would like to point out, however, that unjustified imitation of source text structures in the translation text as well as an excessive substitution of semantic components due to the hermeneutical aspect of translation known as overtranslation - which would also account for the greater lengths of translation texts - can on no account be taken as proof of translations constituting separate sorts of texts, but rather seem to indicate less than competent work. What in my opinion would justify to establish translations as separate sorts of texts, could only be the fact that a translation must in all cases be a text that has at least been understood once and would, therefore, show a higher degree of intelligibility, a higher communication index, which I am going to propose in the next section of this paper. The fact remains, though, that the differing lengths of translation texts as compared to source texts due to structural differences of the respective languages are of interest for professional work and would invite a systematic study by linguists.

3.2. Text typologies of source texts have been developed with a view to matching source texts and translation texts and have been applied mainly in two fields, translation quality assessment and the choice of adequate translation techniques.

3.2.1. As to translation quality assessment the study by Reiss (1971) is often quoted where on the basis of text-immanent criteria she postulates three types of texts, called inhaltsbetont (content-oriented), formbetont (form-oriented), and appellbetont (appellative), which have to be kept equivalent in an adequate translation. I have had occasion elsewhere (Bühler 1976) to point out the limited practicability of her programmatic model. Another model of translation quality assessment by House (1977) in which she distinguishes between two types of translation, covert and overt translation - though demonstrated by the author on a corpus of textual pairs - is mainly intended for use in the classroom. For the 
professional translator translation evaluation is linked with its functional aspect. It is open to question whether there exists such a thing as a theoretically good translation at least for the translator to whom the relation to the reader (=buyer) of his translation is often more important than that to the author of the source text. This lack of confidence of translators in theoretical models of translation quality assessment does not override the fact, however, that professional organizations, which are sometimes called upon as arbitrators in disputes concerning the quality of translations, do have an interest in the development of objective criteria.

3.2.2. As to text typologies established with a view to the choice of adequate translation techniques, a research project reported on by Thiel (1974a) and Wilss (1977:146 f.) seems to be geared to the didactics of translation mainly. The same holds true for another more recent publication by Reiss (1976), where in further developing her model of 1971 she postulates three types of texts, which she calls informativ, expressiv and operativ. In her book the author concentrates mainly on the third type, the operative text, and the translation technique required for it, at the same time questioning herself the feasibility of translating some texts of this type (Reiss 1976:87 f.). It seems, however, that typological studies that could be put to use in the practice of translation would have to consider only those types of texts that are actually encountered in practical work (cf. also Thiel 1974 a:128).

3.3. In taking the translator's point of view I would like to suggest a typology of source texts that anticipates a development that can be expected for the near future. A translator's work falls into two main categories : texts that are written to be translated (which is the case for instance in many publications originally written in rarer languages or documents prepared for international organizations) and, on the other hand, texts the author of which does not envisage translation when preparing his text. I have termed the first sort of texts translationoriented or communicative texts and the second one non-translation-oriented or expressive texts. The author of translation-oriented texts is a) informed that his text is to be translated, he expects a translation and is interested in its successful completion, and he is b) willing to make concessions with a view to optimum translatability (cf. the comment in Wilss 1977:141 on the classification of texts as to translatability by Neubert). The author of texts that are not translationoriented is a) either not aware that his text will be translated, or b), though informed of the fact, is not willing or able to make concessions with a view to improving translatability. The latter category will to a large extent fall into the realm of expressive texts (using the terminology of Reiss 1976), where language is used by the author mainly as a means of self-expression. The first category of texts written with translation in mind, where language is used by the author above all for the purpose of communication and which $I$ have therefore termed communicative texts, can be assumed to constitute an ever increasing part of the professional work of interpreters and translators. Here authors having a vital interest (that can often be expressed in terms of money) in increasing the speed and reliability of the translation of their texts can be expected to prepare or 
present their texts with a view to optimum translatability, provided they are given adequate instruction. It will, therefore, be the task of translators and interpreters and their professional organizations in cooperation with linguists and academic institutions where translation is taught to establish, and make available to the public, guidelines for authors to ensure optimum translatability. Since, however, so far the limits of translatability as well as typical difficulties to be encountered in translation have received more attention than ways to facilitate translation in preparing source texts written to be translated I would like to make a few tentative suggestions in this respect in the remaining section on source text analysis of this paper.

\section{Source Text Analysis}

It seems important at this stage to remember that the translation process comprises two phases, decoding and encoding or analysis and synthesis, involving the understanding of the source text and verbal restructuring of the translation text. Translatability could therefore be optimized by facilitating either phase.

4.1. Restructuring, which at least in interpreting can be compared to a normal speech act (Willett 1974:103) does, however, not constitute a specific difficulty of professional work. Let me by way of illustration quote an interpreter, stating that working in his booth from languages $B, C, D, E$ into language $A$ while listening with all his heart and soul to $B, C, D, E$, he is usually unaware of the transfer into A (Dargel 1977:87). The same will be true in a limited way of translators, since also the success of a translation rests mainly on the translator's precise understanding of whatever it is that the original wants to convey. Assuming that we are dealing with an ideal translator (cf. Kirchhoff 1974:142), who has native or near-native competence in the target language, restructuring - at least in what Reiss (1971) calls content-oriented texts - cannot be a problem that is much different for translators than for other language users. Moreover, since quite often translation or interpretation of a text is envisaged into more than one target language, an increase of translatability by devising source texts with a view to facilitating restructuring does not seem practicable.

4.2. It is, therefore, the phase in the translation process that involves the understanding of the source text that deserves our special attention since it is here that problems specific to translation may arise. A translator apparently is a receptor sui generis and it can be assumed that the decoding of a source text required from translators or interpreters in doing their work differs in some respects from that of a normal reader or listener (cf. Koller 1974:48 and Kirchhoff 1974:146 in the discussions following the presentation of their papers). The investigation of what might be termed übersetzerisches Verstehen (translatory comprehension) constitutes a still unexplored field of interdisciplinary research. I can therefore only repeat what Schmidt (1978:52) stated in his recent report on so-called communicative text theories, that the problem of understanding verbal texts (including the process of reception and interpretation) is one of the central subjects of linguistics and that perhaps linguistic theories could be ranked according to their ability to explain the complex process of understanding. 
4.3. It seems that translatability will show a marked correlation with intelligibility and that it is by facilitating the decoding phase that translation could be optimized. Thus the intelligibility of a source text could be rated by means of a communication index that might at the same time serve as a measure for translatability. It would have to comprise both linguistic criteria, such as standardized terminology and syntactic structures (cf. Wilss 1977:150 as to stereotypes in so-called technical texts) as well as above all cognitive criteria that positively influence understanding, involving the organization of the text, the identification of which would require interdisciplinary cooperation with cognitive psychology within the framework of discourse studies (cf. van Dijk/Kintsch 1978). In setting up such a rating the descriptive analysis of practical work, for instance that of interpreters who succeed in an adequate transfer of highly complex messages if presented systematically, but find it next to impossible to translate confused discussions even if vocabulary and syntax are quite simple, seems to commend itself before setting up prescriptive criteria.

4.4. We should, thenefore, pay increased attention to the study of source text analysis, which is the conscious effort to master the decoding phase of the translation process. It still seems to constitute the weakest point in the curriculum offered to students in the field of translation (cf. Ettinger 1977) and in practical work is left entirely to the translator's intuition. Attempts at a systematic study of source text analysis with a view to the teaching of translation, such as the one by Thiel (1974 b) have not gone far beyond a preliminary stage. Moreover, in view of what has been said above as to the nature of the translation process I cannot agree with the author that a translator's analysis of the source text must at all events be carried out with a view to translation into a particular language (sprachpaarbezogen) (cf. Thiel 1974b: 183). It rather seems that the process of understanding, of arriving at what we may call sense, is irrespective of the target language. Nothing is known as to the time sequence of the phases of the translation process, but, as has been said before, the translator is often aware of a non-verbal link between the two. It appears to me that the study of notational strategies in consecutive interpretation, where neither source language nor target language seem to play a dominant role (cf. Seleskovitch $1975: 161$ ), might shed some light on this question.

Hownever, the analysis of a text as part of the translation process probably differs characteristically from other models of text analysis. Thus, in view of the importance of source text analysis for translation and the fact that text comprehension and text processing constitute favorite topics of current research within the framework of discourse studies, whose interdisciplinary nature is stressed (cf. Schmidt 1978, van Dijk 1978), it seems surprising that a cooperation between linguists and translators is not envisaged. So in the remaining minutes $I$ would like to suggest at least two areas where translators with their specific problems could serve as test cases for linguists and might in turn benefit from the outcome of their research.

4.4.1. Both translators and interpreters are aware of the fact that in decoding a message the significant unit for disambiguation will often go far 
beyond the sentence. But while the translator usually has the complete text including a wide range of additional information at his disposal, the interpreter often will not be in the same favorable situation. Studies as to how much of a text must be known and how much information is required for an adequate transfer of the content of a message into the target language as well as to the role of text anticipation in interpretation will find the notions of semantic macrostructures and topic of discourse useful as proposed by van Dijk (1978).

4.4.2. Finally let me point out another fact - so far generally overlooked in the theoretical study of the translation process, yet encountered almost daily by translators and interpreters when performing their work - that it is characteristic of human translation (as opposed to machine translation) that correct understanding is possible in spite of serious phonetic shortcomings or syntactic or semantic errors in the message. In such cases the translator or interpreter is nevertheless expected to guarantee communication by an adequate transfer of the intended message, which again often can only be derived from suprasentential units. The charity principle, which must be applied in such instances, has been discussed in connection with the professional code of ethics of translators, but constitutes a still unexplored field of linguistic research. The criterion of sense constancy included in the six-stage model of understanding proposed by Schmidt (1978:57) implying that we expect what we hear or read to make sense, and that we analyse the incoming message so as to conform to this criterion, seems to be relevant in this respect. A study of the error-correcting code that becomes effective here will have to be taken up by linguists and incorporated into any theory of language understanding (cf. also Hofmann 1977).

\section{Concluding Statement}

In conclusion let me extend an invitation to all experts concerned with translation studies or discourse studies to pay a visit to the workshop of translators, who in turn might profit from their subsequent findings when performing their duties. I hope to have succeeded here in making a few suggestions as to those areas where such a cooperation might be profitable.

\section{REFERENCES}

BÜHLER, H., Kategorien und Kriterien für eine fachgerechte Beurteilung von Übersetzungen, in : Mitteilungsblatt des Österreichischen Übersetzerund Dolmetscherverbandes, July 1976.

DARGEL, N., The spirit and the letter, in : AIIC Bulletin, Vol. V, No. 3, November 1977, 87-89.

DRESSLER, W., Textsyntax und Übersetzen, in : P. Hartmann/H. Vernay (eds.), Sprachwissenschaft und Übersetzen, München, 1970, 64-77.

_-, Textgrammatische Invarianz in Übersetzungen, in : E. Gülich/W. Raible (eds.), Textsorten, Frankfurt/M., 1972, 98-112.

- Einführung in die Textlinguistik, 2nd rev. ed., Tubingen, 1973.

- Der Beitrag der Textlinguistik zur Übersetzungswissenschaft, in : V. Kapp (ed.), Übersetzer und Dolmetscher, Heidelberg, 1974, 61-71. 
ENKVIST, N.E., Kontrastive Textlinguistik und Übersetzung, in : Grazer Linguistische Studien 5, Spring 1977, 47-73.

HOFMANN, Th. R., Unpopular Comments on Semantic Theory, Paper presented at the XIIth International Congress of Linguists, Vienna, 29.8-2.9.1977.

HOUSE, J., A Model for Translation Quality Assessment, Tübingen, 1977.

KAISER, H., The Faithful Translator : Some Hints on the Teaching of Translation Technique, in : S.M. Kahn/M. Raetz (eds.), Interculture, Wien-Stuttgart, 1975, 103-111.

KIRCHHOFF, H., Psychologische Aspekte des Übersetzens, in : W. Wilss/G. Thome (eds.), Aspekte der theoretischen, sprachpaarbezogenen und angewandten Sprachwissenschaft, Heidelberg, 1974, 119-147.

KOLLER, W., Anmerkungen zur Definition des Übersetzungsvorganges und zur Übersetzungskritik, in : W. Wilss/G. Thome (eds.), Aspekte der theoretischen, sprachpaarbezogenen und angewandten Sprachwissenschaft, Heidelberg, 1974, 34-55.

KRATKY, K.W., Computerlinguistik. Auswertung spezieller Texte, Beziehung zur Theorie, Vol. 1, 2, Berichte der österreichischen Gesellschaft für Kybernetik, January 1976.

REISS, K., Möglichkeiten und Grenzen der Übersetzungskritik, München, 1971.

-., Texttyp und Übersetzungsmethode. Der operative Text, Kronberg/Ts., 1976.

SCHMIDT, S.J., Some Problems of Communicative Text Theories, in : W.U. Dressler (ed.), Current Trends in Textlinguistics, Berlin-New York, 1978, 47-60.

SELESKOVITCH, D., Langage, langues et mémoire, étude de la prise de notes en interprétation consécutive, Paris, 1975.

- Why Interpreting is not Tantamount to Translating Languages, in : AIrC Bulletin, Vol. V, No. 3, November 1977, 76-86.

THIEL, G. (a), Ansätze zu einer Typologie deutscher und französischer Texte, in : W. Wilss/ G. Thome (eds.), Aspekte der theoretischen, sprachpaarbezogenen und angewandten Sprachwissenschaft, Heidelberg, 1974, 118-132.

- (b), Ansätze zu einer Methodologie der übersetzungsrelevanten Textanalyse, in : V. Kapp (ed.), Übersetzer und Dolmetscher, Heidelberg, 1974, 174-185.

VAN DIJK, T.A., New Developments and Problems in Textlinguistics, AILA Bulletin, No. 1 (22), 1978, 13-26.

VAN DIJK, A.T./KINTSCH, W., Cognitive Psychology and Discourse, in : W.U. Dressler (ed.), Current Trends in Textlinguistics, Berlin-New York, 1978, 61-79.

WILLETT, R., Die Ausbildung zum Konferenzdolmetscher, in : V. Kapp (ed.); Übersetzer und Dolmetscher, Heidelberg, 1974, 87-109.

WILSS, W., Übersetzungswissenschaft. Probleme und Methoden, Stuttgart, 1977. 